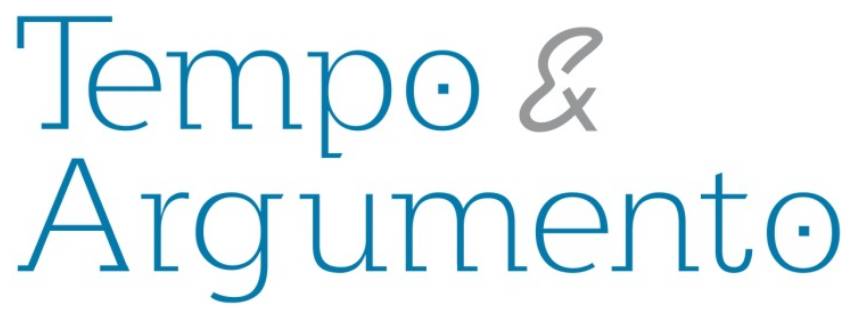

\title{
Gritos, susurros y silencios dictatoriales. La historiografía chilena y la dictadura pinochetista
}

\begin{abstract}
Resumen
Este artículo revisa la producción historiográfica chilena respecto de la dictadura, liderada por el general Augusto Pinochet. El artículo sostiene que el período dictatorial no ha generado en Chile un campo/área de estudios consistente y que perdure en el tiempo, pues la atención ha estado concentrada más bien en su proyección a la post dictadura y las responsabilidades de los gobiernos civiles en sus continuidades, como en las vías de construcción al socialismo y la experiencia chilena de la Unidad Popular. Tal derrotero se relaciona con el debate político en Chile sobre el desmontaje de esa herencia. Ello ha incidido en una producción desbalanceada, con temas excesivamente analizados, otros de menos repercusión y muchos más, abandonados. Gritos, susurros y silencios son las metáforas que expresan tales tendencias.
\end{abstract}

Palabras clave: Dictadura. Historiografía. Chile.

Pinochet.

\section{Para citar este artículo:}

VALDIVIA ORTIZ DE ZÁRATE, Verónica. Gritos, susurros y silencios dictatoriales. La historiografía chilena y la dictadura pinochetista. Tempo e Argumento, Florianópolis, v. 10, n. 23, p. 167 - 203, jan./abr. 2018.

\section{DOI: $10.5965 / 2175180310232018167$}

http://dx.doi.org/10.5965/2175180310232018167

\author{
Verónica Valdivia Ortiz de Zárate \\ Doctora en Estudios Americanos por la \\ Universidad de Santiago de Chile. Profesora \\ Titular, Escuela de Historia de la Universidad \\ Diego Portales. \\ CHILE \\ veronicavaldiviaoz@gmail.com
}




\title{
Dictatorial Shouts, Whispers and Silences. Chilean Historiography and Pinochet's Dictatorship
}

\begin{abstract}
This article reviews the historiography concerning the Chilean dictatorship led by General Augusto Pinochet. It claims that the dictatorial period has not established, at least in Chile, a consistent and sustained field of studies, as attention has tended to focus more on its repercussions in the postdictatorial period and the complicities of civilian governments on such continuities, as well as on the different "roads" to socialism and the experience of the Popular Unity. These emphases are connected to Chile's current political debates about the feasibility or desirability of dismantling Pinochet's legacies, with their attendant incidence on an unbalanced historiographic production: some topics have been analized in excess, others have received less attention, and many more have been simply ignored. Shouts, whispers and silences are the metaphors here employed to convey those tendencies.
\end{abstract}

Keywords: Dictatorship. Historiography. Chile.

Pinochet.

Se suele afirmar que Chile es un "país de historiadores", expresión acuñada en referencia a los padres de la historiografía chilena en el siglo XIX, quienes construyeron la imagen del naciente país, en un momento, según Sergio Villalobos, en que éste requería una visión de sí mismo. La afirmación alude a la fuerte influencia de esos insignes historiadores decimonónicos, no solo en la academia, sino en la opinión pública, pues, a la vez que historiadores, ejercían destacados cargos políticos, y sus ideas y debates eran

\footnotetext{
${ }^{1}$ La expresión corresponde al intelectual español Marcelino Menéndez y Pelayo, quien afirmó que Chile era un país de historiadores y de juristas.
} 
importantes en esa opinión. Hoy en día, a doscientos años de esa pléyade, si bien los historiadores no ejercen cargos político-institucionales, la Historia y Ixs historiadores siguen siendo parte importante del debate nacional. El historiador Gabriel Salazar se convirtió en un referente de los movimientos sociales en los últimos años y sus tesis historiográfico-políticas fueron usadas para las luchas de variados gremios. Traigo esto a colación, para señalar que la Historia en Chile es una disciplina con fuerte atracción pública, como lo demuestra la transformación de la editorial Lom² en un "fenómeno social", hoy la principal editora de historiografía nacional, bajo cuyo ejemplo han nacido numerosas editoriales más pequeñas que absorben la creciente demanda social por leer libros de Historia, como la de jóvenes historiadores por publicar. La Colección Historia de Lom es la más importante de la editorial, siendo uno de sus más relevantes éxitos la Historia contemporánea de Chile, de los historiadores Gabriel Salazar y Julio Pinto, una historia en cinco volúmenes, la cual puso en cuestión las periodizaciones consagradas y el enfoque con que se abordaba la historia nacional. Dos años antes, el sociólogo Tomás Moulian estremeció a la academia y a la clase política con su agudo análisis de las continuidades entre dictadura y democracia en Chile actual. Anatomía de un mito, libro con más de 20 reediciones (MOULIAN, 1997). Más aún, en los últimos años numerosos historiadoras/res se han convertido en figuras permanentes en algunos programas de televisión, de entretención, destinados a discutir temas de la historia nacional, con destacados niveles de teleaudiencia. ${ }^{3}$ Guiándose por estos antecedentes generales, al parecer a las/os chilenos les gusta leer y saber de historia de Chile. Esta demanda social es un fenómeno surgido a finales de la dictadura pinochetista, pero especialmente de las últimas dos décadas y ella refiere tanto a la historia reciente chilena, como a sus grandes héroes decimonónicos.

Este es un fenómeno interesante, considerando que Chile es un país fracturado por su historia reciente, especialmente los turbulentos años sesenta, la Unidad Popular, la dictadura y la post dictadura, quiebre socio-interpretativo, que tiene su proyección en el

\footnotetext{
${ }^{2}$ La editorial fue creada en 1990 por víctimas de la represión de la dictadura pinochetista.-

${ }^{3}$ El programa "Culturas verdaderas", dedicada a conversar temas de historia de Chile, fue separada de su alma mater, "Mentiras verdaderas", donde tenía un espacio, debido a su éxito, dedicándole el programa en su totalidad, el que cuenta con un historiador como panelista estable y otros historiadores como invitados, dependiendo del tema a conversar.
} 
previsión), que ha marcado y marca la vida cotidiana de las/os chilenas/nos, y la fuerte resistencia de quienes se identifican con dicho proyecto. En ese sentido, hoy, la historia y la política convergen con más fuerza que nunca.

Precisamente, la idea de "Chile, país de historiadores", como actores con fuerte influjo social, alude a una historiografía muy politizada, en estrecha conexión con la contingencia. Esta situación se ha expresado con claridad a partir de los años ochenta, cuando la "Nueva Historia Social”, encabezada por Gabriel Salazar, desafió la imagen del Chile construida por los historiadores clásicos, y la tesis de la derecha y de sus intelectuales de que el golpe de 1973 se relacionaba estrictamente con los años anteriores al golpe de Estado, con los procesos de transformación estructural iniciados a mediados de los años sesenta: la reforma agraria, la insurgencia popular, la amenaza al capital que Ilevó adelante la Unidad Popular. Salazar sostuvo, en cambio, que el quiebre remitía a la formación y crisis de la sociedad popular chilena del siglo XIX. La "Nueva historia social” retrotrajo el origen de los conflictos y el análisis histórico a etapas muy anteriores al golpe y la dictadura, a procesos de larga duración, pero estrechamente ligados a los combates políticos y por la memoria de los años ochenta y noventa. No obstante, en la práctica, por sus temáticas, se alejaba de la historia reciente. (SALAZAR, 1985) Esta situación no fue revertida por los primeros trabajos de la "Nueva Historia Política", cuyo principal exponente en los años noventa, Alfredo Jocelyn-Holt, se focalizó en el siglo XIX para auscultar el autoritarismo del país (JOCELYN-HOLT, 1992, 1997). Y, aunque, publicó un interesante libro sobre la historia reciente chilena (JOCELYN-HOLT, 1998), su línea de trabajo es una historia general de Chile, emulando al principal historiador liberal del siglo XIX.

En suma, si bien la historia reciente era de interés social, en los debates historiográficos de los años noventa predominaban los estudios del siglo XIX.

No obstante ello, los historiadores ocuparon un relevante sitial con y a partir del hito que fue la detención del general Pinochet en Londres en octubre de 1998, pues ello 

estabilidad, sin retrocesos autoritarios (DRAKE; JAKSIC, 1998). El apresamiento de Pinochet por crímenes de lesa humanidad desató un fuerte debate nacional acerca de la violación de derechos humanos en tiempos de la dictadura y los límites de la justicia alcanzada (LIRA; LOVEMAN, 2000, 2002), como la mantención del neoliberalismo y su impacto en la post dictadura, entre quienes criticaban el camino seguido por la Concertación (los "autoflagelantes") y quienes se enorgullecían (los “auntocomplacientes”) (BOENINGER, 1998; CORTAZAR; VIAL, 1998).

En ese debate, los historiadores adquirieron gran protagonismo al enfrentarse distintas interpretaciones del pasado reciente. Gonzalo Vial Correa, el principal historiador de la derecha, autor de El libro blanco del cambio de gobierno en Chile (VIAL, 1973), ${ }^{4}$ había estado difundiendo una historia del siglo XX chileno en formato de fascículos, publicados por el diario derechista La Segunda, de la red de El Mercurio. A ello se sumó la "Carta a los chilenos", enviada por el general Pinochet desde su encierro en Londres, en la cual entregaba su versión acerca del golpe y el papel de la "subversión" en ello. En tal escenario, un grupo de historiadorxs publicaron un Manifiesto de Historiadores, en el cual rebatían las tesis de Vial, Pinochet y la derecha: “De un tiempo a esta parte hemos percibido un recrudecimiento notorio de la tendencia de algunos sectores de la sociedad nacional a manipular y acomodar la verdad pública sobre el último medio siglo de la historia de Chile, a objeto de justificar determinados hechos, magnificar ciertos resultados y acallar otros; casi siempre con el afán de legitimar algo que difícilmente es legitimable y tornar verdadero u objetivo lo que no lo es o es solo la autoimagen de algunos grupos" (GREZ; SALAZAR, 1998). El Manifiesto de Historiadores alcanzó una importante resonancia social, colocando a la historia en el centro de la discusión. El Manifiesto de Historiadores

\footnotetext{
${ }^{4}$ Este libro fue publicado en octubre de ese año, respondiendo a la condena internacional por la violación de derechos humanos producida con el golpe y la denominada "Caravana de la muerte", los asesinatos de dirigentes de la Unidad Popular, detenidos en distintos regimientos del país. El libro argumentaba la existencia de un supuesto plan de autogolpe de la UP y el programado asesinato de altos dirigentes de la oposición y de oficiales de las fuerzas armadas. El golpe habría buscado impedir este llamado "Plan Z".
} 
reivindicaba la urgencia de un debate sobre la historia reciente y resaltaba la deuda que la historiografía tenía con ella. De alguna manera, una agenda de trabajo quedó delineada.

Fue a partir de entonces que la historia reciente fue conformándose como un campo/área de estudio, donde numerosas tesis, proyectos de investigación y reflexiones se concentraron en los últimos cincuenta años de la historia nacional, incorporando nuevos enfoques y metodologías. A ello colaboró la reforma curricular que el gobierno de Eduardo Frei Ruiz Tagle promovió desde 1997, dentro de la cual el currículum de Historia fue uno de los más importantes, ya que integró el pasado reciente (PINTO, 1999). Desde entonces, los libros de texto y los programas de estudio deberían incorporar el período de la Unidad Popular, la dictadura y el tema de los derechos humanos. La consolidación de la historia reciente fue, igualmente, de la mano de la "Nueva Historia Política”, aquella que dialogaba con la sociología, la ciencia política, la antropología, y participaba de la renovación metodológica que significó el "testimonio" y el rescate de la subjetividad de los sujetos. La “historia oral” y el trabajo de campo adquirió centralidad en el quehacer de Ixs historiadores, pero especialmente referido a la recuperación de los testimonios de las víctimas de la dictadura (GARCÉS, 1994; GARCÉS; LEIVA, 2005). A inicios del segundo milenio, la "memoria" hizo su entrada triunfal, copando parte sustancial de los trabajos sobre militancia y violación de derechos humanos.

En consonancia, la dictadura pinochetista era la impulsora de esta nueva historiografía y atravesaba, explícita o tácitamente, los estudios que surgieron a partir de entonces. Sin embargo, su derrotero no se dirigió del todo hacia esa experiencia, sino lo hizo preferentemente al período que lo antecedió (1965-1973), objetivo de la crítica de la oposición derechista-dictatorial. Un segundo período de interés corresponde a la post dictadura (1990-2010) a la que se sindica de haber consolidado el proyecto dictatorial, núcleo de la discusión actual. Con todo, una imagen de la dictadura surgió de esa explosión.

Es importante señalar que el presente artículo solo considera la producción de historiadores chilenos y no incluye la extranjera, salvo contadas excepciones. Tampoco ahonda en trabajos periodísticos o memorias personales, aunque no las excluye del todo. 
He dividido este escrito en tres secciones, intituladas con una metáfora de lo que, a mi entender, ha sido la trayectoria de la historiografía chilena sobre la dictadura.

"Gritos" alude a las temáticas más abordadas y contingentes, que exceden a la academia. "Susurros" refiere a temas que han buscado relevar las complejidades de la dictadura y que han alcanzado una resonancia más limitada, tanto en el ámbito académico como socio-político. "Silencios", finalmente, pretende llamar la atención a aquellos aspectos de la dictadura poco o nada explorados y el estado actual de la historiografía chilena.

Antes bien, haremos un breve recuento de los planteamientos de sociólogos y politólogos, quienes sentaron las primeras tesis acerca del origen, la naturaleza y la periodización de la dictadura.

\section{Los primeros enfoques}

La brutal represión ejercida desde los primeros momentos del golpe de Estado en septiembre de 1973, provocó un enorme impacto entre los partidos de izquierda y la sociedad chilena, dominada por una imagen del país como democrático, ajeno a golpismos y violencias, institucionalista, pluralista, respetuoso de los derechos. La violencia estructural que envolvió a la dictadura y su adscripción capitalista incidieron en una lectura que enfatizó el corte histórico que significó el golpe y su naturaleza. Planteada por ex militantes de la Unidad Popular, los primeros estudios no dudaron en calificar a la dictadura como "fascista”, poniendo especial atención en su alianza de clase con la burguesía nacional (CARMONA, 1973; REISMANN; RIVAS, 1976; ROJAS MIX, 2007).

El giro neoliberal de la dictadura encabezada por el general Pinochet superó la anterior concepción fascista por la del Estado Burocrático Autoritario y su alianza con la alta burguesía transnacionalizada, planteada por Guillermo O’Donnell para las dictaduras del Cono Sur. En esa óptica, el objeto de estudio se centró en las fuerzas armadas y la evolución ideológica vivida por ellas a lo largo del siglo XX. Flacso fue el principal centro de estudios que dedicó los primeros esfuerzos a entender a las que se identificaban como protagonistas del golpe y la dictadura consiguiente. Augusto Varas encabezó esos 
contenido. Ella habría sido colmada por la influencia norteamericana en la post guerra y las tesis de la seguridad nacional, las que fueron acompañadas del reordenamiento económico mundial. Las fuerzas armadas habrían evolucionado del estatismo desarrollista, concordante con el fordismo y el keynesianismo de post $2^{\mathrm{a}}$. Guerra a la economía de mercado, en vías de transnacionalización, que despuntaba en los años setenta (VARAS; BUSTAMANTE; AGÜERO, 1980; ROJAS; VIERA GALLO, 1977).

En la línea que otorgaba una primacía a la influencia estadounidense se insertó la dictadura dentro de los anticomunismos y la Doctrina de Seguridad Nacional, estableciendo que el anticomunismo era un fenómeno de larga data entre las fuerzas armadas chilena. La represión y la arremetida contra el movimiento sindical y la izquierda aparecieron como coherentes con su trayectoria político-ideológica. Siendo dictaduras de seguridad nacional, se caracterizaban por el "terrorismo de Estado" (ARRIAGADA, 1981; ARRIAGADA; GARRETÓN, 1978; VARAS; AGÜERO, 1982; VARAS, 1984; TAPIA, 1980).

Otro grupo de sociólogos se abocó a desentrañar el carácter de la dictadura, intentado superar la imagen exclusivamente represiva, para avanzar a su naturaleza refundacional, la cual rescataba la cuestión proyectual, identificada con el neoliberalismo. La dictadura era, igualmente, represiva que refundacional (GARRETON, 1984). En ese sentido, estos análisis fijaron su atención en la transformación económica. La obra magna sobre este carácter y su proyección a la post dictadura es el libro de Tomás Moulian Chile actual. Anatomía de un mito.

La revolución neoliberal a que dio lugar la dictadura sería producto de los cambios en la economía mundial y de los asesores civiles, adversos al nacional desarrollismo y el capitalismo keynesiano, como a la democracia representativa, partidarios de un orden autoritario y anticomunista. Serían esos civiles quienes habrían empujado la revolución capitalista neoliberal, convenciendo al general Pinochet y habrían luchado por un régimen antidemocrático (FOXLEY, 1982; ARELLANO; CORTÁZAR, 1982; ARRIAGADA, 1998). Una visión alternativa ofreció la tesis que contraponía a la lectura dictatorial, la de régimen 
En suma, las ideas ejes heredadas por estos trabajos provenientes de las ciencias sociales eran su carácter dictatorial, de seguridad nacional, bajo influencia estadounidense, fuertemente represivo. Más que el conflicto interno, se enfatizaba la interferencia externa, norteamericana. Una segunda idea era su alianza con el gran capital, el neoliberalismo y el desmantelamiento del Estado social. En tercer lugar, su apuesta antidemocrática, autoritaria, profundamente excluyente, contrario a la soberanía popular. En materia de periodización, la dictadura exhibía cuatro períodos claros: 19731978, caracterizada por la opción neoliberal y la transformación de la economía chilena; 1978-1982, la época del milagro neoliberal; 1982-1984, la crisis; 1985-1989, la recuperación y consolidación neoliberal. Estas etapas, que seguían la evolución económica, coincidían con la reestructuración política: 1973-78, represión y desmantelamiento político; 19781980, el nuevo plan constitucional, con el general Pinochet a la cabeza, quien debería ser ratificado o no en un plebiscito sucesorio en 1988.

Estos estudios se focalizaron en los cambios institucionales y en los civiles en el poder que los llevaron a cabo. Salvo Varas y sus colegas, la atención no estuvo en los militares como sujetos de cambio, sino en el grupo de economistas provenientes de la Universidad de Chicago, que aplicaron políticas neoliberales, y en Jaime Guzmán y los “gremialistas" -miembros del Movimiento Gremial- que diseñaron el proyecto político, de “democracia protegida”, admiradores de la dictadura franquista.

Lxs historiadores que se abocaron al estudio de la historia reciente chilena tuvieron como referente estos planteamientos. Su objetivo preferente era analizar el macro período de la dictadura-post dictadura, como un continuo, desconociendo la frontera entre dictadura y democracia que los dirigentes políticos y la sociología/politología de la Transición había establecido. Los años noventa y dos mil eran hijas de la dictadura, la que seguía viva en sus núcleos fundamentales. En ese marco debe inscribirse la historiografía chilena de la historia reciente del país. 


\section{Los gritos dictatoriales}

Pocos temas concitan tanta sonoridad social como el neoliberalismo, en tanto implantación forzosa durante la dictadura como su proyección a la post dictadura. A pesar de que los gobiernos de centro-izquierda (Concertación) rechazaron tal acusación, desde el Chile actual, de Tomás Moulian y, poco después, El consumo me consume (1998), la mantención del modelo neoliberal copó la agenda pública, el reclamo social por un sistema de protección y derechos, como la defensa acérrima de sus promotores y partidarios. Ello dio lugar a análisis académicos de mediana duración, que evaluaban la transformación estructural del país entre la dictadura y la expansión de los años noventa, como un gran ciclo. El debate se centró en las continuidades o rupturas y su impacto social, desde una óptica crítica o alabadora (LARRAín; VERGARA, 2003; MUÑOZ, 2007; GARRETÓN, 2012). No obstante, estos estudios, y otros, fueron asumidos casi en su totalidad por los cientistas sociales, especialmente sociólogos y economistas, algo que ya ocurrió cuando Chile se convirtió en un laboratorio. En ese sentido, la tesis prevalente fue que el golpe de 1973 buscaba reponer el papel del empresariado y del capital, desmovilizando a la polítizada sociedad chilena. El carácter neoliberal de la refundación llevada adelante y su profundidad, con la destrucción de la anterior estrategia de desarrollo y de pacto social, sostuvo la tesis de una dictadura revolucionaria, capitalista neoliberal.

La presencia de historiadores en los estudios acerca de la transformación neoliberal llevada a delante por la dictadura es pequeña, pero adhieren a la tesis revolucionaria levantada por la sociología, afirmando que fue la única revolución ocurrida en Chile, desarrollada por una elite tecnocrática-ideologizada. Gárate sostiene la existencia de un ciclo revolucionario que continuó bajo los gobiernos de la Concertación (1990-2000) y el papel de la Corporación de Estudios para Latinoamérica (CIEPLAN) en esa proyección (GÁRATE, 2012). Rolando Álvarez, por su parte, compara los más importantes gremios empresariales de Chile (Confederación de la Producción y el Comercio-CPC) y Perú (Confederación Nacional de Instituciones Empresariales PrivadasCONFIEP) y su papel político en la implantación y consolidación del neoliberalismo en sus respectivos países (ÁLVAREZ, 2014). En una mirada distinta y escudriñando la evolución 
del estatismo en el pensamiento militar, hubo quien discrepó de la tesis de los cambios en el capitalismo mundial como originarios del golpe, sosteniendo la existencia de una herencia estatista entre los oficiales, la que habría tardado siete años en ser reemplazada, requiriendo el recambio de los altos mandos en el Ejército y la Fuerza Aérea y parte de la alta oficialidad. Para los años ochenta el proceso habría concluido y el neoliberalismo se habría convertido en la plataforma ideológica de la alianza cívico-militar en el poder (VALDIVIA, 2003).

Aunque otros trabajos aluden a este proceso neoliberal, no ocupa parte importante de la agenda de Ixs historiadores, permaneciendo bajo la hegemonía de las ciencias sociales. Posiblemente, ello se deba al retroceso que ha vivido la historia económica en la post dictadura, la cual se desarrolla en pequeños núcleos, concentrados en estudios referidos al siglo XVIII, XIX y los inicios del siglo XX, teniendo casi nula participación en el debate sobre el cuestionado modelo neoliberal.

Un área que se desarrolló bastante en la década del noventa y que persiste es la de los movimientos sociales, especialmente de los pobres urbanos y, en los últimos años, el estudiantil, movilizado desde 2011. En ese sentido, la dinamización de estos estudios se relaciona con la post dictadura, aunque con miradas de largo plazo (SALAZAR, 2011, 2012; GARCÉS, 2012).

En relación a los temas sociales, la post dictadura ha sido el período que ha concitado más interés historiográfico de parte de las jóvenes generaciones, especialmente el tema educacional, lo que se ha puesto en evidencia en tesis e investigaciones. En los años ochenta, y de forma aislada, María Angélica Illanes analizó el Estado Benefactor del siglo XX, en materia de salud y de educación, dejando al descubierto su desmantelamiento bajo el neoliberalismo y el impacto sobre los grupos más pobres (ILLANES, 1989, 1990). Posteriormente, la mirada se dirigió a la reforma educacional misma en los años ochenta y el debate entre las apuestas nacionalistaautoritaria y la neoliberal. No obstante, el punto de partida para el surgimiento de esta área de estudio fue el impacto de la reforma educacional-curricular del Presidente Frei Ruiz Tagle (1994-1999), antes mencionada, y la crítica a una educación que acusan de excluir deliberadamente la historia reciente, de modo de mantener el actual modelo 
narrativas acerca de la dictadura. Otra mirada se ha dirigido a las exclusiones culturales, especialmente en espacios fronterizos. Sin embargo, la más grande investigación sobre la educación en Chile es un proyecto general, que parte en 1810 y pretende llegar a 2010, pero aún va en sus primeras fases. Por tanto, no es la dictadura su foco de análisis, existiendo solo algunos trabajos aislados sobre este período (MATAMOROS, 2013; JARA, 2014).

Coincidiendo con la lectura estructural del golpe y, por ende, antiobrera, los primeros trabajos hechos por la sociología analizaron el impacto de la represión sobre el movimiento obrero y su debilitamiento durante la dictadura, estableciendo una periodización que, de alguna manera, seguía la implantación del neoliberalismo. En concreto, una primera etapa de arremetida contra la influencia marxista en los sindicatos, preferentemente urbanos, donde predominó la represión, luego un período de reflujo y la imposición del orden neoliberal (CAMPERO; VALENZUELA; 1984). Desde la historiografía se analizó la derrota del sindicalismo nacionalista-autoritario, el que predominaba entre la oficialidad. Los “oficiales del golpe” habrían buscado mantener el orden sindical anterior, eliminando la influencia y participación de la izquierda marxista, propuesta que fue derrotada por el pinochetismo neoliberalizante, para lo cual fue necesario pasar a retiro a la oficialidad golpista, estatista (VALDIVIA, 2003). Esta tesis fue complementada posteriormente, escrutando las políticas desplegadas por el Ministro del Trabajo, Sergio Fernández, y el intento explícito por generar un nuevo tipo de sindicalismo, individualistaneoliberal (ÁLVAREZ, 2010, 2012). Otros han estudiado los cambios ocurridos en el propio sindicalismo (ARAYA, 2014), que posteriormente derivaron en la actual Confederación Unitaria de Trabajadores, CUT.

Salvo el caso de Araya, el movimiento sindical no ha generado escuela, quedando circunscrito a trabajos aislados, parte de investigaciones más amplias. Recientemente, se ha preparado un libro acerca de la cuestión sindical durante la dictadura y post dictadura desde una óptica crítica, que reúne tanto a sociólogos como historiadores. No obstante, 

encuentran en franco crecimiento, al alero de los enfoques de "paternalismo industrial" y la relación entre clase e identidad territorial.

Si la historia sindical y del movimiento obrero tradicional retrocedió, desde los años ochenta emergió un nuevo sujeto popular, nacido bajo el embrujo del "bajo pueblo", la historia oral y la memoria: los pobladores, habitantes de barriadas y poblaciones de emergencia, los que adquirieron gran protagonismo desde fines de los años sesenta y durante la Unidad Popular, por los cientos de tomas de terrenos urbanos, en demanda de vivienda. Su vínculo con la izquierda radical los hizo objeto de una brutal represión tras el golpe y protagonistas de las protestas contra la dictadura en los años ochenta. La historia de los pobladores se ha convertido en un fértil campo de estudio, en el cual el rescate de sus subjetividades, a través del testimonio, juega un papel central. El foco de esta historiografía es la constitución del sujeto popular y su autonomía respecto de los partidos. Por ello, se concentran en la Unidad Popular o en las jornadas de protesta contra la dictadura entre 1983-1986, reivindicando su carácter de movimiento social, criticando el camino seguido por la transición, que negoció con la dictadura (DELA MAZA Y GARCÉS, 1984; COFRÉ, 2007; LUNECKE, 2000).

El tema que ha concentrado la mayor cantidad de trabajos, medido en tesis, de pre y post grado, artículos, proyectos, libros y, particularmente, testimonios, y en íntima relación con el debate acerca de la polarización político-ideológica de los años sesenta que antecedió al golpe y la represión posterior, remite a la izquierda armada, particularmente al Movimiento de Izquierda Revolucionaria (MIR). En este tema fue donde la historia oral y, posteriormente, la memoria caló más hondo, pues fue un útil recurso para rescatar historias que carecían de mucha/ninguna documentación escrita, pero, también, como opción teórico-metodológica. En términos amplios, estos estudios se han situado desde la óptica de la "resistencia" a la dictadura. Aunque distanciado de la sociología, esta historiografía ha consolidado la imagen de una dictadura aliada con la alta burguesía y las derechas políticas. 
En el caso del Partido Comunista, el historiador Rolando Álvarez fue pionero en la reconstrucción de la historia del partido en los primeros siete años de la dictadura, ferozmente reprimido. Álvarez explicó la ruptura entre un partido contrario a la acción armada, institucionalista, y la creación del Frente Patriótico Manuel Rodríguez, grupo militar del partido, como producto del nacimiento de un nuevo tipo de militante, investigación dentro de la cual los testimonios de sobrevivientes fueron fundamentales para una mirada que ponía el énfasis en la trayectoria vivida al interior del país para explicar el cambio de línea política (ÁLVAREZ, 2003). Álvarez ha desarrollado una línea de trabajo historiográfico respecto del comunismo en Chile, analizando su trayectoria desde los años sesenta, la dictadura y su sobrevivencia en la post dictadura, tras la caída de la URSS (ÁLVAREZ, 2011; RIQUELME, 2009). Si bien hubo/hay otros historiadores abocados al comunismo, Álvarez es quien se ha centrado en la dictadura y en la post-dictadura.

El giro comunista en 1980 y su brazo armado, el Frente Patriótico Manuel Rodríguez, ha sido relacionado con la cultura política del comunismo chileno y la política de masas. Desde otra mirada, se ha relevado la experiencia de los "oficiales" del Frente en la revolución sandinista en la elaboración de la política militar del PC (PÉREZ, 2012, 2015, 2016). Sobre el Frente hay importantes testimonios y análisis periodísticos (ROBLES, 2015; HERNÁNDEZ NORAMBUENA, 2016).

Pero el partido que, sin duda, ha generado más atracción ha sido el Movimiento de Izquierda Revolucionaria (MIR), al que la dictadura seleccionó como el primer partido al que reprimir y desarticular. Los estudios sobre el MIR siguen su trayectoria. Un primer grupo se refiere a su fundación (1965-1967), en Concepción y Santiago, sus primeros dirigentes, la llegada del equipo liderado por el médico Miguel Enríquez y sus influencias ideológicas (SANDOVAL, 1990; VITALE, 1999). Una segunda área de interés son los años de la Unidad Popular, su opción por la vía armada en un proceso que buscaba un camino distinto al socialismo y su trabajo a nivel de base: pobladores, campesinos, estudiantes, sindicatos (SANDOVAL, 2004; PINTO, 2005). El impacto de la dictadura y los primeros años de clandestinidad, destacando su heroísmo, su aislamiento y los sucesivos golpes represivos. El relato luego se dirige a la "Operación retorno", 1978-81, sus intentos guerrilleros y su desarticulación definitiva; para finalizar con el quiebre interno de 1987 

ex militantes, que sobrevivieron y que se refieren al trabajo militar del MIR, sus intentos de formar guerrillas; la crisis interna que derivó en el quiebre y su desaparición (BRAVO, 2012; PALMA, 2015; VIDAURRÁZAGA, 2007). El Centro de Estudios Miguel Enríquez (CEME) organizó un gran seminario en 2015 con motivo de los cincuenta años de la fundación del MIR. El principal interés de quienes abordan esta temática es reivindicar la lucha armada, como respuesta al camino seguido por la Unidad Popular, la vía institucional al socialismo, y la transición, que excluyó a quienes defendían una alternativa de insurrección social y militar.

Otro partido que atrajo la atención fue el Movimiento Juvenil Lautaro, de comienzos de los años ochenta, también defensor de la lucha armada para enfrentar a la dictadura, con una fuerte identidad libertaria y formada por jóvenes populares. Sus “expropiaciones" de alimentos y artículos esenciales para repartirlos en las poblaciones pobres fueron emblemáticas. Desplegó una estrategia de lucha insurreccional y se concentró territorialmente en la zona sur de la capital (ACEVEDO, 2014; ROSAS, 2013, 2014).

Es importante insistir en que la gran mayoría de esta historiografía se ubica políticamente en la izquierda extra-institucional, es decir, fuera de los partidos que conformaban el ala izquierdista de la Concertación; ex militantes, simpatizantes o miembros de pequeñas agrupaciones juveniles, ancladas en las universidades o en colectivos de base. Esta posición política ha incidido en la decisión de recuperar la historia de la izquierda revolucionaria, enfrentando las versiones creadas por la dictadura, la derecha y los gobiernos concertacionistas. Ello tiene su punto de arranque, en parte, en la derrota política de la Unidad Popular, pero también en el camino que siguió la Transición, la que optó por insertarse en la institucionalidad diseñada por la dictadura para derrotarla a través del plebiscito sucesorio planificada por ella. Esta vía pacífica e institucionalista implicó desacreditar a quienes promovían la insurrección popular y la vía armada, y aislar a la izquierda marxista, en particular al Partido Comunista después del atentado del FPMR 
al general Pinochet en 1987. La Transición se hizo desconociendo el papel jugado por la insurrección social y su impacto en la apertura política que posibilitó el triunfo en el plebiscito de 1988 y la derrota de Pinochet.

La historiografía acerca de la izquierda revolucionaria, la vía armada e insurreccional, decidió rescatar su historia de la marginación política y social que caracterizó a los noventa. Ello encontró mucho eco en los historiadores jóvenes y provenientes del mundo popular, y la nueva izquierda en formación.

No obstante, existe también cierta historiografía de los partidarios de la dictadura pinochetista. En primer lugar, el anteriormente aludido Gonzalo Vial, quien realizó una biografía de Pinochet en dos volúmenes, con poca resonancia académica y social (VIAL, 2002; ROJAS, 1998/2000). El principal centro historiográfico de la derecha es el Centro de Estudios Bicentenario, el cual ha publicado algunos trabajos sobre la intervención militar de los años veinte y memorias de militares, como algunas fuentes primarias, como las actas del Consejo de Estado. Una línea de denuncia de la izquierda, acusándola de responsable de la crisis de los años sesenta, se desarrolló en los años noventa, que no fue continuada (ROJAS, 2003). Uno de sus principales exponentes, Alejandro San Francisco está liderando actualmente un trabajo acerca de la historia reciente chilena, programada para catorce tomos, de los cuales tres se le dedicarán a la dictadura.

\section{Los susurros dictatoriales}

Como explicamos antes, con esta metáfora queremos aludir a aquellos estudios que han dirigido su atención a los sujetos que constituyeron los pilares de la dictadura, quienes le ofrecieron su plataforma programática, su propaganda, su proyección política, su base social. En concreto, a las propias fuerzas armadas, sus organismos de seguridad, sus partidarios.

Este enfoque ha buscado entender el origen del golpe, la naturaleza de la dictadura, el arraigo social del autoritarismo, entendiendo que las dictaduras son productos sociales y nunca se sostienen solo en la represión, tesis predominante por 
A pesar que el papel de los civiles colaboracionistas siempre ha estado y estuvo claro, social y académicamente, su estudio y el de los militares ha generado reticencia y hasta rechazo, habiendo una preferencia explícita por la idea de una sociedad que resistió (BASTÍAS, 2013; VIDAURRÁZAGA, 2013). Si bien la metáfora del susurro no da cabal cuenta del impacto de esta historiografía, pues lo aminora, sus temáticas no tienen tanta visibilidad pública ni el atractivo que ejercen las izquierdas revolucionarias, siendo más difícil la conformación de un campo o área de estudio, especialmente para el período de la dictadura.

Ya en los finales de la década del ochenta e inicios de la siguiente, un par de jóvenes historiadores se interrogaba acerca del origen del golpe de 1973 en relación a ciertos actores que visualizaba como parte fundamental de la crisis que antecedió al golpe y que lo preparó: los grupos nacionalistas de ultraderecha, particularmente el caso de "Patria y Libertad", pero sin situarse de forma exclusiva en el período de la Unidad Popular, sino rehaciendo sus expresiones más importantes a lo largo del siglo y su devenir (BENAVENTE, 1982a/b; VALDIVIA, 1992, 1995, 1996). Estas fueron las primeras expresiones de una "Nueva Historia Política", que se alejaba de héroes y batallas, para adentrarse en el autoritarismo, de corte fascista e hispánico.

Considerando que una de las conclusiones que surgió de esos trabajos fue que la ultraderecha nunca tuvo arraigo socio-político en el país y por eso muy tempranamente miró a las fuerzas armadas como el agente que debería dar lugar a la revolución nacionalista antiliberal, el paso siguiente fue estudiar a las fuerzas armadas golpistas y debatir las tesis establecidas por la sociología -Varas-, que aseguraban la existencia de un "constitucionalismo formal" entre los militares, el que habría sido quebrado por la Doctrina de Seguridad Nacional y las tesis de la guerra contrasubversiva, que se habrían convertido en sus nuevos basamentos. En todos los trabajos sobre las fuerzas armadas y el golpe, la influencia ideológica y la intervención norteamericana, la CIA en particular, eran el factor explicativo fundamental (CORVALÁN MARQUÉZ, 2002, 2013). Sin embargo, a partir de estudios acerca de la intervención militar de los años veinte y treinta, y los 
desmantelamiento del Estado intervencionista y su reemplazo por el neoliberal, cuestionando la interpretación unilateral de la seguridad nacional en su versión del enemigo interno, poniendo atención en el desarrollismo. Este análisis sostuvo que al momento del golpe pervivía la anterior doctrina castrense, el "Ibañismo" hasta su reemplazo por el "Pinochetismo" (VALDIVIA, 2003, 2006).

A partir de la tesis del "Pinochetismo" castrense, un joven historiador analizó su subsistencia a comienzos del nuevo milenio, bajo la Comandancia en Jefe del general Juan Emilio Cheyre, el denominado general de la Transición. Cheyre reconoció el carácter institucional de la violación de derechos humanos y afirmó un "Nunca Más". Según Seguel, Cheyre habría conducido la “despinochetización” del Ejército (SEGUEL, 2015).

Esta línea de continuidad en las fuerzas armadas fue complementada posteriormente por Valdivia, a la luz de los enfoques acerca de los "consensos dictatoriales", pues uno de los rasgos que distinguió a la dictadura chilena fue su importante apoyo social y el liderazgo del general Pinochet, el denominado “Pinochetismo". Reflexionando acerca de la tesis del Estado Burocrático de Guillermo O’Donnell y de la guerra revolucionaria de origen francés, se propuso una lectura alternativa, redefiniendo la guerra y sosteniendo que en el caso de Chile, ella se peleó fundamentalmente en los frentes económicos y sociales, considerando el tipo de enfrentamiento ocurrido antes del golpe (VALDIVIA, 2010a/B; 2015; TIMERMANN, 2005). Dicha forma de entender el conflicto político en Chile relevó la importancia que tenía para la dictadura la guerra psicológica y, por tanto, la re-socialización de la politizada sociedad chilena y la fuerte influencia de la izquierda marxista, analizando los brazos políticos de la dictadura y su penetración del mundo popular, destinado a ser neoliberalizado: las Secretarías de la Mujer y de la Juventud (VALDIVIA, 2013). En ese sentido, la dictadura buscó generar la adhesión a Pinochet y el proyecto dictatorial, encarnado en el “pinochetismo", buscando legitimar los cambios económicos, sociales, políticos y culturales llevados adelante. 
Recientemente, se aprobó una tesis doctoral respecto del consenso dictatorial entre algunos segmentos de las clases medias. En concreto, un trabajo que analiza la conformación y comportamiento de los sectores medios que adhirieron a la dictadura en sus primeros años, movilizados contra la Unidad Popular, alianza posteriormente quebrada a comienzos de los ochenta (CASALS, 2017). ${ }^{5}$

Esta línea analítica fue continuada desde la óptica de la diada izquierdas y derechas, contraponiendo el auge de la nueva derecha y el declive de la izquierda histórica (marxista) para inicios de la post dictadura. Esta investigación analizó la muerte de conservadores y liberales, y la aparición de la derecha pinochetista: Unión Demócrata Independiente (UDI) y Renovación Nacional (RN). La primera fue la que suscitó más investigaciones, pues fue quien articuló el proyecto dictatorial y sus bases de apoyo. Para 1997 se había convertido en el partido más grande en términos electorales, a pesar de esa explícita defensa e identificación con la dictadura, permeado por un estilo agresivo y desafiante, profundamente ideológico (VALDIVIA, 2008a/b; 2006; RUBIO, 2013). Uno de los aspectos que despertó más interés fue su carácter "popular", es decir, su capacidad para desafiar los patrones electorales clasistas, logrando votaciones significativas en sectores populares, antes muy izquierdistas. Estos trabajos rastrearon el origen del “pinochetismo popular” (SOTO, 2001; PINTO, 2006; VALDIVIA, 2008). En el último período, la tendencia ha sido a desentrañar la cultura política de sus militantes, interrogando sus subjetividades a través de testimonios (MUÑOZ, 2016).

Considerando el carácter proyectual de la dictadura pinochetista y el tipo de guerra entablada en Chile, también se puso atención en la reorganización del régimen interior con la regionalización llevada adelante desde 1974 y su impacto en el plano político, pero alejándose de los análisis institucionalistas realizados por los cientistas políticos y los sociólogos, concentrados en la Constitución de 1980 y los enclaves autoritarios, deslizándose hacia la escala local. De acuerdo a este enfoque, la resocialización de la sociedad chilena requería su despolitización, la cual se lograría apartando a la población de los partidos y de las problemáticas nacionales, para

\footnotetext{
${ }^{5}$ CASALS Marcelo “Clase media y dictadura en Chile: consenso, negociación y crisis (1973-1983)", tesis doctoral inédita, The University of Wisconsin-Madison, 2017.
} 

social” (VALDIVIA, ÁLVAREZ, DONOSO, 2012).

Esta línea analítica comunal fue continuada para la post dictadura, período en que el proyecto dictatorial fue consolidado. De acuerdo a este enfoque, los municipios constituyeron una importante herramienta para la expansión del neoliberalismo y el autoritarismo, legados por la dictadura (VALDIVIA, 2012, 2013; ÁLVAREZ, 2014; PÉREZ, A., 2014, PÉREZ, A., 2016).

Situándose en los aspectos geopolíticos que se observaban en la dictadura, se indagó sobre las representaciones de la carretera austral, nombrada como Augusto Pinochet, una de las construcciones más destacadas por la dictadura. Su autor sostiene que la carretera expresó los principios políticos del régimen en relación al territorio, la economía y el autoritarismo, atravesados por concepciones geopolíticas (URRUTIA, 2016). Considerando que se trata de una tesis de maestría, aún no es posible determinar si ello se convertirá en un área de estudio.

Una temática que ha surgido entre la generación del Bicentenario, es el de la cultura en dictadura, la que ha analizado la reorganización política a través de la cultura, las políticas culturales, la estética, la música y la televisión como instrumento clave en la guerra psicológica emprendida por el pinochetismo (MUÑOZ, 2006; JARA, 2006, 2011; DONOSO, 2016; DURÁN, 2012; ALBORNOZ, 2005, 2014). La mayoría de estos trabajos apunta a la cultura -especialmente la televisión- como instrumento de despolitización.

Aunque no centrada en la dictadura, concretamente, se comenzó a estudiar a las clases medias, en tanto asociación gremial y cambio en su posición dentro de la sociedad. Uno de los impactos sociales claves de la revolución capitalista llevada a cabo por la dictadura fue la transformación de la clase media, vinculada desde fines del siglo XIX a la expansión estatal, educacional y urbana. El neoliberalismo supuso su reemplazo por nuevos actores, proceso y memoria rastreada por estos trabajos (CANDINA, 2012, 2013). Esta área, sin embargo, no ha sido continuada por otros investigadores. 
A pesar de la actualidad y contingencia de los temas no ha logrado crearse propiamente un campo de estudios de las derechas, de los colaboradores de la dictadura y de la capacidad de ésta para encontrar arraigo en importantes segmentos sociales.

\section{Los silencios dictatoriales}

Como explicamos, hemos decidido utilizar la metáfora de los silencios dictatoriales para referirnos a las temáticas poco o nada abordadas por la historiografía chilena y dar alguna mirada al estado actual de la investigación histórica en Chile y su relación con la dictadura.

Lo primero a señalar es que la dictadura pinochetista, propiamente tal, no es un área de estudio, sino un puente para escudriñar la post dictadura.

La naciente generación (que cursan la Licenciatura o Magíster) en su gran mayoría se siente atraída, como explicamos antes, por la historia de la izquierda revolucionaria, la que reivindican, especialmente aquella que optó por la vía armada. Esto es parte de la discusión actual sobre la inexistencia de un proyecto y una izquierda que se levante como una alternativa política.

La generación nacida en los ochenta, que ya cuenta con un posgrado y ha comenzado a publicar en la presente década tiene como campo la postdictadura. En parte esto se relaciona, a nuestro entender, con su historia personal, cuyo desarrollo intelectual y memoria histórica están asociados a los años de los gobiernos concertacionistas y al debate acerca de su carácter continuista, por haber consolidado el proyecto dictatorial. Muchos de ellas/os fueron dirigentes en los centros y federaciones de estudiantes, o militantes de partidos nuevos y colectivos de izquierda, "víctimas" de la política educacional y social de la Concertación, endeudados. En ese sentido, su objeto de estudio se ha desplazado a la historia más reciente, alimentando el debate político actual desde la historiografía y/o la militancia.

La generación anterior (que ya publicaba en los 2000) ha oscilado entre los estudios acerca de la dictadura (Rolando Álvarez, por ejemplo) y la post dictadura. En el 
caso de Álvarez, debido al papel del Partido Comunista en la transición, sus dos últimos proyectos de investigación se han referido a este último período histórico. De la generación a la que pertenece Álvarez (34 investigadores) siete tienen a la dictadura como un área de trabajo y no de forma permanente, pues varían de temas y períodos.

A su vez, de la generación a la que pertenezco, que estudiamos en los años ochenta, parte de los cuales iniciamos los estudios de historia reciente (15 investigadores destacados), tres tenemos a la dictadura pinochetista como un área permanente de análisis. Otro exponente se ha focalizado en la post dictadura y los demás en otros períodos, incluyendo la Colonia.

En suma, el porcentaje de investigadores dedicados a desmenuzar una etapa tan decisiva en la historia reciente del país es, como se hace evidente, pequeño. Esto y las tendencias descritas en la primera sección han provocado un desbalance en la producción historiográfica, habiendo temas ultra estudiados, sin que aparezcan interrogantes nuevas, mientras otros yacen "en silencio" a la espera de nuevos interlocutores.

Esta interpretación se refuerza al observar los proyectos de investigación aprobados en los últimos concursos, financiados por el sistema estatal del Fondo de Desarrollo Científico y Tecnológico (FONDECYT). En los Concursos Regulares, es decir, de alta competitividad, en el año 2016, de 13 adjudicados, solo uno se refería a la dictadura; mientras que en 2017, de 14 aprobados, ninguno estudiaría la ditadura. En los Concursos de Iniciación, para investigadores jóvenes, que ya tienen el post doctorado, en el año 2016, de 11 proyectos aprobados, solo uno abordaba la dictadura. La gran mayoría eran investigaciones sobre el período colonial, de la post Independencia, la infancia y uno sobre estudios medievales. Una situación similar se encuentra en los concursos regulares y en los post doctorados: es decir, un abanico amplio de temáticas.

En los últimos años se han abierto nuevos campos historiográficos, uno de los más notables es el de formación de Estado en la post Independencia, siglo XIX o los estudios de género o etnicidad. Hoy una de las áreas de estudio más dinámicas es la cuestión indígena, aunque sobrepasa lo ocurrido en dictadura y tiene su punto de arranque en el conflicto actual (PAIRICAN, 2014; MILLALÉN, MARIMÁN, LEVIL Y CANUIQUEO, 2006). Esta 
doctorado, escogiendo sus áreas de investigación acorde a las tendencias, enfoques y miradas de sus unidades de formación. Esta influencia externa ha diversificado los estudios. De allí que muchas veces la opción temática escogida responde a las tendencias historiográficas en boga en Estados Unidos y no en Chile.

Esta evaluación no deja de considerar que el espectro de historiadores en Chile es pequeño, en comparación con los de Brasil, Argentina o México y es posible que ello incida en que la fragmentación sea tan evidente y la dificultad para formar campos de estudio. Al parecer, en Chile cada generación es hija de su tiempo, a lo que se suma la influencia externa.

Otro factor que no debe dejar de estimarse es el difícil acceso a las fuentes. Tomando en cuenta el tipo de transición habido en Chile, con fuerzas armadas que impusieron las condiciones y aseguraron la proyección de su transformación política a la post dictadura, se ha mantenido el control-censura sobre las fuentes. En Chile, no se ha abierto ningún archivo de la dictadura, de sus servicios de inteligencia, de seguridad, tampoco de sus instituciones. Lo mismo ocurre con los archivos de la policía política o de Carabineros, cerrados al acceso público. Más aun, los archivos oficiales de los ministerios de Interior y Defensa, depositados en el Archivo Nacional, solo tienen información útil hasta mediados de siglo XX, inicios de la Guerra Fría. Según la respuesta oficial, esos archivos estaban en la Moneda el 11 de septiembre de 1973, donde se habrían quemado. En el caso del Ministerio Secretaría General de Gobierno, desde donde se desplegaron las estrategias consensuales y el pinochetismo del régimen, simplemente, nunca llegó al Archivo Nacional. La documentación judicial del siglo XX aún se encuentra en un depósito aparte, sin que los investigadores puedan usar su información. En el caso de los archivos de los tribunales militares, en donde se procesaban algunos delitos políticos desde 1925, tampoco son de acceso público. Es posible que ello también haya influido en la preferencia por estudios testimoniales. 
Por otra parte, el alto interés por reconstruir la historia de la izquierda revolucionaria ha oscurecido temas de gran importancia, como la violencia dictatorial, la represión, la que, más allá de la memoria, no ha despertado curiosidad. Los documentos emanados de las organizaciones de derechos humanos; el Informe Rettig (1991), que reconoció dichas violaciones, estableciéndolas como un hecho histórico innegable; y el Informe Valech (2004) sobre represión y tortura, delinearon, de modo general, las etapas, sus organismos, los tipos de represión y sus agentes. Sin embargo, la historiografía no ha generado un área de estudios de la represión, que haya establecido las continuidades y rupturas respecto de tipos de coerción y alcances. Aunque en el caso de Chile la tortura no era una práctica de las fuerzas armadas, sino de la policía contra los delincuentes, recién en los últimos años han empezado a rastrearse algunas expresiones previas y los dispositivos coercitivos. Lo mismo ocurre con los estudios acerca de los días finales de la Unidad Popular, cuando comenzaron los allanamientos, solicitados por el Poder Judicial, alcaldes y políticos de oposición (LIRA, LOVEMAN, 2013; VALDIVIA, 2014, 2017). Considerando el centralismo que caracteriza a Chile, poco se ha indagado sobre las particularidades de la represión entre la escala nacional, regional o local, existiendo solo algunos estudios aislados (MONSÁLVEZ, 2014, 2015; VALDÉS, 2012). La colaboración civil, el papel del empresariado, de la judicatura y de algunos gremios se encuentra en pañales. En materia represiva, las delaciones que posibilitaron cientos de detenciones, son un tema casi inexplorado, habiendo solo destacadas excepciones (FUENTES ; MATAMOROS, 2012 ). En el último período se comenzó a estudiar la represión desde la perspectiva de género, desde el testimonio (HINER, 2009). Sin embargo, no existen estudios acerca de la infancia en dictadura; ni la apropiación de niños bajo cautiverio de sus padres, como tampoco la aparición y desaparición de los centros de detención.

Ello ha significado que parte importante de las publicaciones acerca de los aparatos represivos sigan recayendo en el periodismo de investigación, el que, en los últimos años, ha descubierto algunos documentos de la DINA, y el testimonio de un participante de la represión, entonces adolescente, que ha colaborado en algunos casos de detenidos desaparecidos (DORAT y WEIBEL, 2014; REBOLLEDO, 2012, 2013, 2015). Desde la sociología se ha propuesto una tipología de "modelos de horror" para analizar la 
el del gobernante. Por lo tanto, la forma en que organizan la coerción es clave para el desarrollo de cualquier gobierno, pero particularmente en las experiencias dictatoriales (POLICZER, 2014).

Una excepción importante a esta despreocupación historiográfica es el trabajo desarrollado por Gabriel Salazar, Premio Nacional de Historia 2006 y prisionero político de la dictadura. En años recientes, ha historiado el principal campo de tortura y desaparición de la dictadura pinochetista: el "Cuartel Terranova", conocido como Villa Grimaldi. Como víctima e historiador, su trabajo camina por la frontera entre historia y memoria. Salazar instala la historia de la dictadura pinochetista dentro de la crisis del capitalismo del siglo XX y la reacción monetarista neoliberal, dirigida a una terapia de shock de orden humano, económico y constituyente. Ello requirió al plan norteamericano la adecuación de las fuerzas militares, las que debieron ser adoctrinadas para lograr el "enquistamiento sociocultural en los ciudadanos... La exoneración, la prisión, el exilio, la tortura y la muerte podían lograr eso en tiempo record... Por eso, la task force no podía ser un aparato civil... sino una fuerza armada en terreno" (SALAZAR, 2013, p.59). El volumen I del texto describe y analiza la acción "militar" de la DINA en el "Cuartel Terranova" (Villa Grimaldi), mientras que el volumen II refiere a la militancia, el exilio, la memoria y el retorno (SALAZAR, 2017).

Sin duda, el trabajo de Salazar representa un importante esfuerzo para desentrañar las lógicas de la represión dictatorial, sus efectos socio-culturales y complejidades. El material contenido en la Corporación para la Paz, Villa Grimaldi; del Colectivo Londres 38, centro de detención, tortura y desaparición; del Museo de la Memoria y los Derechos Humanos, entre otras organizaciones, constituyen un incentivo al estudio de la represión.

Precisamente, por este contexto es que el libro de Freddy Timmermann y su particular enfoque constituyen un notable aporte. Timmermann se ha concentrado en la generación y el impacto del miedo para analizar el terror dictatorial en sus primeros siete 

amenaza. El autor trabaja con análisis de discurso (TIMMERMANN, 2015).

En estrecha relación con la represión, tampoco se han vuelto a analizar los derroteros doctrinarios de las fuerzas armadas en el siglo XX, que derivaron en el terror estatal. La influencia de la Doctrina de Seguridad Nacional, como sinónimo de enemigo interno y de represión, se ha dado como verdad inamovible (con la excepción de la tesis del "Ibañismo"), sin que se haya incursionado en lecturas menos rígidas. Tampoco se ha auscultado más sobre el impacto de la geopolítica (salvo las menciones ya hechas), o la guerra contrainsurgente de origen francés, que permitan historizar las experiencias. Sabemos que las teorías caen en culturas, historias y culturas políticas concretas, que le dan a los fenómenos sus particularidades. El carácter personalista de la dictadura chilena, el Pinochetismo, no fue una casualidad, ni un efecto del maquiavelismo del general Pinochet, solamente, sino de un Chile con un historial específico.

Si la represión es un área no investigada, otras están aún más soterradas. Tal es la situación del Poder Judicial, tema en el que solo existen tesis de Derecho y el estudio pionero de Lira y Loveman, que atraviesa el siglo XX y le dedica a la dictadura aproximadamente cinco capítulos de los 34 que conforman sus dos volúmenes. Igual abandono existe sobre actores tan importantes como fueron los abogados de derechos humanos; o el Comité Pro Paz, primer organismo que acogió a los familiares de las víctimas y elaboró los primeros archivos de detenidos; lo mismo para la Vicaría de la Solidaridad o la Agrupación de Familiares de Detenidos Desaparecidos y la Agrupación de Ejecutados Políticos. Estas organizaciones mantienen sus archivos y elaboran documentos, pero su papel histórico en la resistencia y lucha por la defensa de los derechos humanos no ha concitado mayor atención,

Algo similar ha ocurrido con los estudios respecto de las derechas. Los trabajos acerca del papel de los grupos de la derecha radical, nacionalistas de distinto signo, llegan, en su casi totalidad, a 1973, siendo muy excepcionales los referidos a la época de la dictadura. La Secretaría de los Gremios, que los albergó durante la dictadura, casi no ha 
la falta de atención a sus historias. En Chile se suele pensar que la derecha radical es muy marginal, sin importancia, hipótesis que fue desmentida por las investigaciones de los noventa antes mencionadas, demostrándose el impacto que tuvieron en determinados hitos y en su alianza con la derecha institucional y las fuerzas armadas. Esas relaciones ambivalentes entre la derecha radical y la institucional deben seguir siendo interrogadas, pues su protagonismo en momentos de crisis es crucial.

Respecto de los partidos, casi no existen estudios. Hay algunas memorias de la renovación socialista y algo historiográfico desde esa perspectiva (VALENZUELA, 2014; MOYANO, 2011), prácticamente nada de la Democracia Cristiana, que ha jugado un papel clave en los años sesenta, en el golpe y en la Transición. Hay muy poco acerca del otro partido de derecha, Renovación Nacional, porque la mayoría se concentró en la UDI. EI rechazo al actual sistema de partidos incide en este abandono y la preferencia por repensar una nueva izquierda.

La gama de temas que casi no ha sido explorados es tan amplia como la complejidad de la dictadura. Por el momento, las nuevas generaciones no parecen estar interesadas en escudriñarla, aunque su superación definitiva lo amerita de forma urgente. 


\section{Referencias}

ACEVEDO, Nicolás. Mapu-lautaro. Concepción, Chile: Escaparate. 2014.

ALBORNOZ, Cesar. La experiencia televisiva en el tiempo de la Unidad popular. In: PINTO, Julio (Ed.). Fiesta y drama: nuevas historias de la unidad popular. Santiago: Lom, 2014. p. 143-172.

ALBORNOZ, Cesar. La cultura en la Unidad Popular. In: PINTO, Julio. Cuando hicimos historia: la experiencia de la unidad popular. Santiago: Lom, p.147-176, 2005.

ÁLVAREZ, Rolando. Gremios empresariales: política y neoliberalismo, los casos de Chile y Perú (1986-2010). Santiago: Lom, 2014.

ÁLVAREZ, Rolando. Arriba los pobres del mundo! Cultura e identidad política del Partido Comunista de Chile entre democracia y dictadura, 1965-1990. Santiago: Lom, 2011.

ÁLVAREZ, Rolando. El Plan Laboral y la negociación colectiva ¿origen de un nuevo sindicalismo en Chile? (1979-1985).In: RAVIGNANI, Emilio. Boletín del Instituto de Historia Argentina y Americana, n. 35-36, 2012.

ÁLVAREZ, Rolando. ¿Represión o integración? la política sindical del régimen militar (19731980). Historia, v. II, n.43, p.325-355, 2010.

ÁLVAREZ, Rolando. Desde las sombras: un estudio de la clandestinidad comunista (19731980). Santiago: Lom, 2003.

ARAYA, Rodrigo. Cambios y continuidades en el movimiento sindical chileno en los años ochenta: el comando nacional de trabajadores. Historia, v.l, n.47, p.11-37, 2014.

ARELLANO, José Pablo; CORTÁZAR, René. Del milagro a la crisis: algunas reflexiones en torno al momento económico. Estudios Cieplán, n.8, 1982.

ARRIAGADA, Genaro. El pensamiento político de los militares. Santiago: Cesoc, 1981.

ARRIAGADA, Genaro. Por la razón o la fuerza: Chile bajo Pinochet. Santiago:

Sudamericana, 1998.

ARRIAGADA, Genaro; GARRETÓN, Manuel Antonio. América Latina a la hora de la Seguridad Nacional. In: PÉREZ, M. A. (Ed.). Las fuerzas armadas en la sociedad civil. Santiago: Cisec, 1978.

BASTÍAS, Manuel. Sociedad civil en dictadura: relaciones transnacionales, organizaciones y socialización política en Chile. Santiago: Ediciones Universidad Alberto Hurtado, 2013. 
BENAVENTE, Andrés. La alternativa nacionalista bajo el régimen militar. Santiago: ICHEH, $1982 a$.

BENAVENTE, Andrés. La derecha política en el régimen militar chileno, 1973-.1981. Santiago: ICHEH, 1982b.

BOENINGER, Edgardo. La democracia en Chile. Santiago: Andres Bello, 1998.

BRAVO, José Manuel. De Carranco a Carrán: las tomas que cambiaron la historia.Santiago: Lom, 2012.

CAMPERO, Guillermo; VALENZUELA, José. El movimiento sindical en el régimen militar chileno. Santiago: Ilet, 1984.

CANDINA, Azun. La clase media como ideal social en Chile contemporáneo. Dossier Chile contemporáneo, n.29, 2012. Disponível em: <www.historiapolitica.com>. Acesso em: 2007-2017

CANDINA, Azun. (Ed.). La frágil clase media: estudios sobre los grupos medios en Chile contemporáneo. Santiago: UCH, 2013.

CARMONA, Fernando. El fascismo chileno, lección para América Latina. México: Instituto de Investigaciones Económicas Problemas del desarrollo, 1973.

CASALS, Marcelo. Clase media y dictadura en Chile: consenso, negociación y crisis (19731983). Tesis doctoral inédita, The University of Wisconsin-Madison, 2017.

COFRÉ, Boris. Campamento Nueva La Habana: el MIR y el movimiento de pobladores, 1970-1973. Escaparate, 2007.

CORTAZAR, René; VIAL, Joaquín (Ed.). Construyendo opciones. Santiago:

Dolmen/Cieplán, 1998.

CORVALÁN, M. Luis. La secreta obscenidad de la historia de Chile contemporáneo: lo que dicen los documentos norteamericanos y otras fuentes documentales, 1962-1976. Santiago: Ceibo, 2013.

CORVALÁN, M. Luis. Los partidos políticos y el 11 de septiembre. Santiago: Cesoc, 2000.

DELA MAZZA, Gonzalo; GARCÉS, Mario. La explosión de las mayorías. Santiago, 1984.

DONOSO, Fabián. Memoria, labor e identidad docente: apuntes para una historia social de los profesores de historia durante la dictadura, 1982-1990. In: JORNADAS DE HISTORIA DE CHILE, 20, Iquique, 2013. 
DONOSO, Karen. ¿Canción huasa o canto nuevo? la identidad chilena en la visión de izquierdas y derechas. In: VALDIVIA, Verónica et al. Su revolución contra nuestra revolución., v.l. n. 2, p. 231-290, 2008.

DORAT, Carlos; WEIBEL, Mauricio. Asociación ilícita: los archivos secretos de la dictadura, DINA. Santiago: Ceibo, 2014.

DRAKE, Paul; JAKSIC, Iván. El modelo chileno. Santiago: Lom, 1998.

DURÁN, Sergio. Ríe cuando todos estén tristes: el entretenimiento televisivo bajo la dictadura de Pinochet. Santiago: Lom, 2012.

FOXLEY, Alejandro. Los experimentos neoliberales en América Latina. Santiago: Cieplán, 1982.

FUENTES, Miguel; MATAMOROS, Christián. Dejaron al gato cuidando la carnicería:el delator en el sindicato de panificadores de la serena 1973-1987. Universum, v. 27 n.2, p.8198,2012 .

GÁRATE, Manuel. La revolución capitalista en Chile (1973-2003). Ediciones Universidad Alberto Hurtado, 2012.

GARCÉS, Mario. El despertar de la sociedad: los movimientos sociales en América Latina y Chile Santiago: Lom, 2012.

GARCÉS, Mario. La historia oral: enfoques e innovaciones metodológicas. Taller de Historia Local. PUC, 1994.

GARCÉS, Mario. Recreando el pasado: guía metodológica para la memoria y la historia local. ECO, 2002.

GARCÉS, Mario; LEIVA, Sebastián. El golpe en la legua. Lom, 2005.

GARRETÓN, Manuel Antonio. Neoliberalismo corregido y progresismo limitado: los gobiernos de la concertación en Chile, 1990-2010. Santiago: Arcis, 2012.

GARRETÓN, Manuel Antonio. El proceso político chileno. Santiago: Flacso, 1984.

GREZ, Sergio; SALAZAR, Gabriel (Comp.). Manifiesto de historiadores. Santiago: Lom, 1998.

GOICOVIC, Igor. Movimiento de izquierda revolucionaria. Concepción: Escaparate, 2012. 
GONZÁLEZ, Fabián; AREYUNA, Beatriz (Ed.). Pedagogía, memoria e historia crítica: una mirada educativa a los discursos y lugares de la memoria. Santiago: Ediciones Academia de Humanismo Cristiano, 2014.

HERNÁNDEZ NORAMBUENA, Mauricio Hernández. Un paso al frente: habla el comandante ramiro del FPMR. Santiago: Ceibo, 2016.

HINER, Hillary. Voces ignoradas, violencias soterradas: discurso, violencia política y género en los informes Rettig y Valech. Latin America Researche Review, v. 44, n. 3, p. 5074, 2009.

HUNEEUS, Carlos. El régimen militar de Pinochet. Santiago: Sudamericana, 2000.

ILLANES, María Angélica. En el nombre del pueblo, del Estado y de la ciencia: historia social de la salud pública de Chile, 1880-1973. Santiago: Colectivo de Salud Primaria, 1989.

ILLANES, María Angélica. Ausente, señorita. Santiago: Junaeb, 1990.

JARA, Isabel. De Franco a Pinochet: el proyecto cultural franquista en Chile, 1936-1980. Santiago: Universidad de Chile, 2006.

JARA, Isabel. Graficar una segunda Independencia: el régimen militar chileno y las ilustraciones de la Editorial Nacional Gabriela Mistral (1973-1976), Historia, v. 44, n.1, 2011, p.131-163.

JARA, Isabel. Vivir una dictadura: historia y memoria de los profesores de Chile (19731990). Historia 396, n. 2, 2014.

JOCELYN-HOLT, Alfredo. La Independencia de Chile. Madrid: Madfre, 1992.

JOCELYN-HOLT, Alfredo. El peso de la noche. Nuestra frágil fortaleza histórica. Santiago: Planeta, 1997

JOCELYN-HOLT, Alfredo. El Chile perplejo. Santiago: Editorial Planeta, 1998.

LARRAÍN, Felipe; VERGARA, Rodrigo (Ed.). La transformación económica de Chile entre 1973 y 2003. Santiago: Centro de Estudios Públicos, 2000.

LIRA, Elizabeth; LOVEMAN, Brian. Poder Judicial y conflictos políticos (1925-1958). Santiago: Lom, 2013.

LOVEMAN, Brian; LIRA, Elizabeth. Las ardientes cenizas del olvido: vía chilena de reconciliación política. Santiago: Lom, 2000. 
LOVEMAN, Brian; LIRA, Elizabeth. El espejismo de la reconciliación política. Chile, 19902002. Santiago: Lom, 2002.

LUNECKE, Graciela. Violencia política: (violencia política en Chile 1983-1986). Santiago: Arzobispado de Santiago, 2000.

MILLALÉN, José; MARIMÁN, Pablo; LEVIL, José ; CANIUQUEO, Sergio. ¡Escucha winka! Santiago: Lom, 2006.

MATAMOROS, Christián. Represión e imposición organizativa: los primeros años del colegio de profesores de Chile 1974-1981. In: SEMINARIO DA REDE DE PESQUISADORES DE ASSOCIATIVISMO E SINDICALISMO DE TRABALHADORES EM EDUCAÇOA, 4, Niteroi, 18-20 abr. ,2012. Anales... Brasilia: Paralelo 15, 2013, p.105-120.

MONSÁLVEZ, Danny. Extremistas, antipatriotas e indeseables: la legitimidad del golpe de Estado de 1973 en la prensa escrita de concepción y el origen del 'Plan Z'. Concepción: Escaparat, 2015.

MONSÁLVEZ, Danny. Los bandos militares en Concepción y Talcahuano: disciplina militar y disciplinamiento social. Concepción: Escaparate, 2014.

MOULIAN, Tomás. El consume me consume. Santiago: Lom, 1998.

MOULIAN, Tomás. Chile actual: anatomía de un mito. Santiago: Lom, 1997.

MOYANO, Cristina. El Mapu durante la dictadura: saberes y prácticas políticas para una macrohistoria de la renovación socialista. Santiago: Ediciones Universidad Alberto Hurtado, 2011.

MUÑOZ, Oscar. El modelo económico de la concertación ¿entre reformas o cambio?.Catalonia: Editorial Catalonia, 2007.

MUÑOZ, Víctor. Historia de la UDI: generaciones y cultura política. Santiago: Ediciones Universidad Alberto Hurtado, 2016.

MUÑOZ, Víctor. ACU. Santiago: Calabaza del Diablo, 2006.

PAIRICAN, Fernando. Malón: la rebelión del movimiento mapuche, 1990-2013. Santiago: Pehuén, 2014.

PALMA, José. EI MIR y su opción por la guerra popular: estrategia político-militar y experiencia militante. Concepción: Editora Escaparate, 2015. 
PÉREZ, Claudio. La tarea militar del Partido Comunista de Chile ¿continuidad o ruptura de la política militar del comunismo chileno?. Izquierdas, n. 29, p.49-82, 2016.

PÉREZ, Claudio. El Frente antifascista y la política militar del Partido Comunista de Chile. Tempo e argumento, Florianópolis, v. 7, n. 16, p.154-182, 2015.

PÉREZ, Claudio. De la guerra contra Somoza a la guerra contra Pinochet: la experiencia internacionalista y la formación de una fuerza militar propia del Partido Comunista de Chile. In: POZZI, Pablo; PÉREZ, Claudio (Ed.). Historia oral e historia política: izquierda y lucha armada en América Latina (1960-1990). Santiago: Lom, 2012. p.213-244.

PÉREZ, Aníbal. La UDI tras el telón. Agitación social, lavinismo y clientelismo: el caso de Virginia Reginato en Viña del Mar. Local: América en Movimiento, 2016.

PÉREZ, Aníbal. ¿UDI popular? los campamentos y el respaldo electoral-popular de derecha. El caso de Virginia Reginato en Viña del Mar (2008-2013). Izquierdas, n. 21, p. 130, 2014 .

PINTO, Carolina. UDI: la conquista de corazones populares (1983-1987). Santiago: A\&V, 2006.

PINTO, Julio. La reforma curricular en el área de historia y ciencias sociales: propuestas y debates. Revista chilena de humanidades. UCH, n. 18-19, 1999.

PINTO, Julio. Hacer la revolución" In: PINTO, Julio (Ed.) Cuando hicimos historia. La experiencia de la Unidad Popular, Santiago, Lom, 2005, pp.9-34 ESTA ES LA REFERENCIA CORRECTA

PINTO, Julio; LEIVA, Sebastián. Punto de quiebre. El MIR en los ochenta. In: VALDIVIA, V. et al. Su revolución contra nuestra revolución: la pugna marxista-gremialista en los ochenta. Santiago: Lom, p. 85-135, 2008.

POLICZER, Pablo. Los modelos del horror: represión e información en Chile bajo la dictadura militar. Santiago: Lom, 2014.

REBOLLEDO, Javier. A la sombra de los cuervos. Santiago: Ceibo, 2015

REBOLLEDO, Javier. El despertar de los cuervos:tejas verdes, el origen del exterminio en Chile. Santiago: Ceibo, 2013

REBOLLEDO, Javier. La danza de los cuervos: el final de los detenidos desaparecidos. Santiago: Ceibo, 2012. 
REISMANN, Elizabeth; RIVAS, Fernando S. Las fuerzas armadas de Chile: un caso de penetración imperialista. Editora De Ciencias Sociales: La Habana, 1976.

RIQUELME, Alfredo. Rojo atardecer: el comunismo chileno en dictadura y democracia.Dibam, 2009.

ROBLES, Javiera. Memorias de la clandestinidad: relatos de la militancia femenina del frente patriótico Manuel Rodríguez. Nomadías, n. 19, p. 85-103, 2015 .

ROSAS, Pedro. Por la senda del Lautaro... latinoamérica vencerá: discurso, acción política, concepción y dimensión internacional del Mapu-Lautaro, 1982-2004. 2014 Tesis (Doctoral) - USACH, 2014.

ROSAS, Pedro. De la lucha contra Pinochet a la 'democracia cartucha:representaciones y semblaza histórica e historiográfica del Mapu-Lautaro. Tiempo y Espacio, n. 30, 2013

ROJAS, Gonzalo. La agresión del oso: intervención soviética y cubana en Chile, 1959-1973. El Roble, 2003.

ROJAS, Gonzalo. Chile escoge la libertad. La presidencia de Augusto Pinochet Ugarte. 11.IX.1973-11.III.1990. Santiago: ZigZag, 1998/2000. 2 vol.

ROJAS, Jaime; VIERA-GALLO, José Antonio. La Doctrina de Seguridad Nacional y la militarización de la política en América Latina. Roma: Chile-América, Centro de Estudios y Documentación, 1977.

ROJAS MIX, Miguel. El dios de Pinochet: fisonomía del fascismo iberoamericano. Buenos Aires: Prometeo, 2007.

RUBIO, Pablo. Los civiles de Pinochet la derecha en el régimen militar chileno, 1982-1990. Dibam, 2013.

SANDOVAL, Carlos. Movimiento de Izquierda Revolucionaria: 1970-1973. Coyunturas, documentos y vivencias. Concepción: Escaparate, 2004.

SANDOVAL, Carlos. MIR: una historia. Santiago: Sociedad Editorial Trabajadores, 1990.

SALAZAR, Gabriel. Voces profundas: los compañeros y compañeras "de" Villa Grimaldi. Santiago: Lom, 2017.v. 2

SALAZAR, Gabriel. Villa Grimaldi (cuartel terranova) historia, testimonio, reflexión: funcionamiento y rutinas represivas del principal centro de detención, tortura y exterminio. Santiago: Lom, 2013. 
SALAZAR, Gabriel. Movimientos sociales en Chile: trayectoria histórica y proyección política. Santiago: Lom, 2012.

SALAZAR, Gabriel. En el nombre del poder constituyente. Santiago: Lom, 2011.

SALAZAR, Gabriel. Labradores, peones y proletarios. Santiago: SUR, 1985.

SEGUEL, Felipe. “Un Ejército para la paz. Las bases para el cambio doctrinario en el Ejército de Chile (2002-2006)", Bogotá, Revista de Relaciones Internacionales, Estrategia y Seguridad, No.11-1, 2016, pp.219-238-

SOTO, Ángel. La irrupción de la UDI en las poblaciones, 1983-1987.Washington: Ponencia presentada al congreso de Lasa, 2001.

TAPIA VALDÉS, Jorge. Terrorismo de Estado. México: Nueva Imagen, 1980.

TIMMERMANN, Freddy. El gran terror: miedo, emoción y discurso, 1973-1990. Ediciones Universidad Raúl Silva Henríquez, 2015.

TIMMERMANN, Freddy. El factor Pinochet: dispositivos de poder, legitimación [i.e. legitimación], elites Chile, 1973-1980.Santiago: Ediciones Universidad Raúl Silva Henríquez, 2005.

URRUTIA, Santiago. El sueño por una carretera: carretera austral, representaciones sociales y geopolítica durante la dictadura militar chilena, 1973-1990. 2016. Tesis (Magíster) - UCH, 2016.

VALDÉS URRUTIA, Mario. El golpe de Estado del 11 de septiembre de 1973 en Concepción (Chile): las voces de los testigos. Cuadernos de Historia, n. 37,p. 159-191, 2012.

VALDIVIA, Verónica. Subversión, coerción y consenso: creando el Chile del siglo XX. Santiago: Lom, 2017.

VALDIVIA, Verónica. La derecha pinochetista en el post pinochetismo. Auge y crisis del lavinismo, 2000-2004. Estudos Iberoamericanos, n. 42, v.2, p.694-723, 2016.

VALDIVIA, Verónica. La democracia dictatorial: regionalización y municipios. Avances del cesor, n. 12, v. 1, p. 171-187, 2015.

VALDIVIA, Verónica. Pinochetismo e guerra social. In: MOTA, Rodrigo Patto Sá. Ditaduras militares en Brasil, Argentina, Chile, Uruguai. Belo Horizonte: EFMG, 2015. p. 121-142.

VALDIVIA, Verónica. Chile ¿un Estado de excepción? La Ley de control de armas y la máquina represiva puesta en marcha. In: PINTO, Julio (Ed.).Fiesta y drama: nuevas historias de la Unidad Popular. Santiago: Lom, p. 205-232, 2014. 
VALDIVIA, Verónica. Were women and younth people the heart the pinochet regime? rise and decline of the secretariats. Hispanic America Historical Review (HAHR), v. 93, n.4, p.547-583, 2013.

VALDIVIA, Verónica. El Santiago de Ravinet: despolitización y consolidación del proyecto dictatorial en el Chile de los noventa. Historia, n. 46, v. 1, 2013, pp.177-219.

VALDIVIA, Verónica. La alcaldía de Joaquín Lavín y el 'lavinismo' político en Chile.Dossier n. 29. 2012. Disponível em: <www.historiapolitica.com>. Acesso em: 30-06-2017.

VALDIVIA, Verónica. Construction du pouvoir et régimen militaire sous Augusto Pinochet. Vingtième Siècle, n. 105, p.93-108,jan./ mar., 2010a.

VALDIVIA, Verónica. ;Estamos en guerra, señores: el régimen militar de Pinochet y el 'pueblo', 1973-1980. Historia, n. 43, v. 1, p. 163-201, 2010 b.

VALDIVIA, Verónica. Nacionales y gremialistas: el 'parto' de la nueva derecha política chilena(1964-1973). Santiago: Lom, 2008a.

VALDIVIA, Verónica. Del ibañismo al Pinochetismo. In: ZAPATA, Francisco (Comp.). Frágiles suturas: Chile a treinta años del gobierno de Salvador Allende. México: Colegio de México, p. 157-194, 2006.

VALDIVIA, Verónica. El golpe después del golpe: leigh vs pinochet (1960-1980). Santiago: Lom, 2003.

VALDIVIA, Verónica. Camino al golpe: el nacionalismo chileno a la caza de las fuerzas armadas. Santiago: Serie de investigaciones, n. 11, 1996.

VALDIVIA, Verónica. Nacionalismo e ibañismo. Santiago: Serie de Investigaciones, n. 8, 1995.

VALDIVIA, Verónica. El nacionalismo chileno en los años del frente popular. Santiago: Serie de Investigaciones, n. 3, 1995.

VALDIVIA, Verónica; ÁLVAREZ, Rolando; DONOSO, Karen. La alcaldización de la política: los municipios en la dictadura pinochetista. Santiago: Lom, 2012.

VALDIVIA, Verónica; PINTO, Julio; ÁLVAREZ Rolando: LEIVA Sebastián: DONOSO, Karen. Su revolución contra nuestra revolución: la pugna marxista-gremialista en los ochenta.Santiago: Lom, 2008b. 
VALDIVIA, Verónica; PINTO, Julio; ÁLVAREZ, Rolando. Su revolución contra nuestra revolución: izquierdas y derechas en el chile de pinochet (1973-1981). Santiago: Lom, 2006.

VALENZUELA, Esteban Teo. Dios, Marx... y el Mapu. Santiago: Lom, 2014.

VARAS, AUGUSTO; BUSTAMANTE, Fernando; AGÜERO, Felipe. Chile, democracia, fuerzas armadas, Santiago, Flacso, 1980.

VARAS, Augusto. El proyecto político militar, Santiago, Flacso, 1984.

VARAS, Augusto; AGÜERO, Felipe. El desarrollo doctrinario de las fuerzas armadas chilenas. Santiago: Flacso, 1982.

VERGARA, Pilar. Auge y caída del neoliberalismo en Chile. Santiago: Flacso, 1985.

VIAL, Gonzalo. Pinochet: La biografia. Santiago: El Mercurio/Aguilar, 2002.

VIAL, Gonzalo. El libro blanco del cambio de gobierno en Chile. Santiago: Editorial Lord Cochrane, 1973.

VIDAURRÁZAGA, Ignacio. Martes 11: la primera resistência. Santiago: Lom, 2013 .

VIDAURRÁZAGA, Tamara. Mujeres en rojo y negro: memoria de tres mujeres miristas, 1971-1990. Ediciones América Libre, 2007.

VITALE, Luis. Contribución a la historia del MIR (1965-1970). Ediciones Instituto de Investigación de Movimientos Sociales Pedro Vuscovic, 1999. 